\title{
Socio-economic and political status of panchayats Elected representatives (A Study of Mysore District-Karnataka)
}

\author{
H. M. Mohan Kumari ${ }^{1}$ and Dr. Ashok Kumar, $\mathrm{H}^{2}$
}

\begin{abstract}
The paper presents the structure and functions of Panchayati raj Institutions. It also highlights the social composition of elected members and their participation in the decision making process in PRIs. Liberal Democracy is one of the basic features of the Indian Constitution. Mahatma Gandhi advocated Panchayat Raj even before Independence. The further of the Nation felt that as issues at the village levels must be addressed by the people only under self-governance and the State or the Central Governments only facilitate such self-rule through grants and by conferring autonomy on them. Panchayat system had earlier an informal setup to redress the local issues and problems of communities which were mainly social and economic in nature. They were popular institutions at micro levels and the main objective was to keep the local community in harmony and to encourage participation in the process of development. The Mysore Government in 1902 passed the Mysore Local Boards Act with a view to revitaling the rural local Government. In 1918, the Mysore Government enacted the Mysore Local Boards and Village Panchayat Act making provisions for elected representatives at the district and taluk levels. After Independence, District and Taluk Boards were set up by the Mysore Government. The first independent legislation on Panchayat Raj Institutions was enacted by the Ramakrishna Hegde Government in 1983 and was brought into effect from April 1987 with the first elections to these local bodies in rural areas. This was amended during 1993. The salient features of the Karnataka Panchayat Raj Act 1993 are: To establish a 3-tier Panchayat Raj System of elected bodies. Reservation of seats to SC/ST and 50\% seats to women at all levels; reservation of seats to persons belonging to other backward classes. Reservation of offices of Chairpersons in favour of SC/ST, women and backward classes. Establishing Finance Commission and District Planning Committee. Constituting a State Panchayat Council. Mysore district consists of seven revenue taluks, namely, H.D. Kote, Hunsur, K.R. Nagar, Nanjangud, Periyapatna, T. Narasipura and Mysore (Urban and Rural). For administrative purposes, Mysore district is divided into two sub-divisions, which are Hunsur and Mysore and the district has 1,216 villages, 11 statutory towns, 235 grama panchayats and 226 wards. The District Commissioner is responsible for managing the district administration and the Assistant Commissioners are responsible for managing the sub-divisions of the district. Objectives of the Study; To study the socio-economic and political background of the rural political leadership. To examine the nature of the power, structure of the panchayat raj leadership in mysore district, Karnataka. To analyse the problems in implementation of the rural development activities of the panchayats in mysore district, Karnataka. The methodology consists largely of methods of primary survey, namely the questionnaire survey and individual interviews. The primary sources of data are the collected from panchayats elected members in the mysore district. The mysore district has 235 Grama Panchayats (GPs) in which 23 (10 per cent) respondent to a questionnaire. The total number of GPs elected members is 4300, of which 215 (05 per cent) of respondent to a questionnaire. Samples were selected from all the taluks of the district.
\end{abstract}

Word Key: PRIs, presidents, members, Socio, Economic, political

\section{Introduction}

The paper presents the structure and functions of Panchayati raj Institutions. It also highlights the social composition of elected members and their participation in the decision making process in PRIs.

Liberal Democracy is one of the basic features of the Indian Constitution. Mahatma Gandhi advocated Panchayat Raj even before Independence. The further of the Nation felt that as issues at the village levels must be addressed by the people only under self-governance and the State or the Central Governments only facilitate such self-rule through grants and by conferring autonomy on them. Panchayat system had earlier an informal setup to redress the local issues and problems of communities which were mainly social and economic in nature. They were popular institutions at micro levels and the main objective was to keep the local community in harmony and to encourage participation in the process of development.

The Mysore Government in 1902 passed the Mysore Local Boards Act with a view to revitaling the rural local Government. In 1918, the Mysore Government enacted the Mysore Local Boards and Village Panchayat Act making provisions for elected representatives at the district and taluk levels. After Independence, District and Taluk Boards were set up by the Mysore Government. The first independent legislation on Panchayat Raj Institutions was enacted by the Ramakrishna Hegde Government in 1983 and was brought into 
effect from April 1987 with the first elections to these local bodies in rural areas. This was amended during 1993.

The salient features of the Karnataka Panchayat Raj Act 1993 are:

1. To establish a 3-tier Panchayat Raj System of elected bodies.

2. Reservation of seats to SC/ST and 50\% seats to women at all levels; reservation of seats to persons belonging to other backward classes.

3. Reservation of offices of Chairpersons in favour of SC/ST, women and backward classes.

4. Establishing Finance Commission and District Planning Committee.

5. Constituting a State Panchayat Council.

\section{Grama Panchayat}

\section{Structure of PRIs}

Section 4 of the PRI Act provides for constituting Panchayat for the area comprising of a village or group of villages having a population of 5000 and not more than 7000 . The functions of the Gram Panchayat are mentioned in Section 51 provide for 31 functions with three Standing Committees. Namely, Production committee, Social justice committee and Amenities committee.

\section{Taluk Panchayat Samiti}

Section 145 of the Act lists four main functions with 28 detailed functions to be performed by the Panchayat. The functions are mainly supervisory and to monitor the progress of the schemes. There are three standing committees like the Finance, Auditing and Planning committee, General Standing committee and social justice committee.

\section{Zilla Panchayat}

Section 184 of the Act lists four main functions and 29 detailed functions are given in Schedule III. There are 5 Standing Committees: Finance, Audit and Planning Committee, General Standing Committee, Social Justice Committee, Education and Health Committee and Agriculture and Industries Committee.

The district lies between $11^{\circ} 30^{\prime} \mathrm{N}$ and $12^{\circ} 50^{\prime} \mathrm{N}$ Latitudes and $75^{\circ} 45^{\prime} \mathrm{E}$ and $77^{\circ} 45^{\prime} \mathrm{E}$ Longitudes. It is bounded on the north by Hassan, Mandya and Bangalore districts; and on the south by Chamarajanagara district (from 1997) and Kannur district of Kerala State. On the east also, it is bounded by Chamarajanagara district and on the west by Kodagu district, besides Wynad district of Kerala State (Figure 3.1). Physiographically, the region in which the district is situated may be classified as partly maidan (plains) and partly semi-maidan of the Mysore plateau.

The total geographical area of the district is $6,854 \mathrm{~km}^{2}$ being sixth in rank among the districts in the State in its size. Some of the places belonging to Mysore district are of great antiquity. Thirumukudalu Narasipur and Hemmige being prehistorical sites. The district is mainly drained by the Cauvery River, besides the Kabini and the Lakshmanathirtha, which are the tributaries of the Cauvery. Irrigation by canals is a characteristic feature of the district. The climatic conditions of the district are congenial for the development of horticultural crops. The livestock wealth of the district is considerable and progress has been evidenced in the development of poultry rearing, dairying and inland pisci-culture. Industrially, it stands fourth in the number of factories and third in the labour force in 1985-86 and the district is not however well endowed with rich mineral wealth.

\section{Administrative Set Up}

Mysore district consists of seven revenue taluks, namely, H.D. Kote, Hunsur, K.R. Nagar, Nanjangud, Periyapatna, T. Narasipura and Mysore (Urban and Rural). For administrative purposes, Mysore district is divided into two sub- divisions, which are Hunsur and Mysore and the district has 1,216 villages, 11 statutory towns, 235 grama panchayats and 226 wards. The District Commissioner is responsible for managing the district administration and the Assistant Commissioners are responsible for managing the sub-divisions of the district.

There are 7 revenue administrative blocks and 9 educational blocks. Mysore block is divided into two educational blocks, namely, Mysore Urban and Mysore Rural. Mysore Urban is further bifurcated into subeducational blocks, namely, Mysore North and Mysore South, for administrative purposes. H.D. Kote and Nanjangud blocks have vast geographical areas because of the forests. Nanjangud block has a large number of grama panchayats in the district and this is due to larger populations of the block compared to the remaining blocks of the district. Apart from the above, the district has 9 municipalities, 1 City Corporation (Mysore), 7 taluk panchayats, 46 Zilla Panchayat Constituencies, 1 Parliamentary Constituency and 11 assembly constituencies. 


\section{Objectives of the Study:}

1. To study the socio-economic and political background of the rural political leadership.

2. To examine the nature of the power, structure of the panchayat raj leadership in mysore district, Karnataka.

3. To analyse the problems in implementation of the rural development activities of the panchayats in mysore district, Karnataka.

\section{Methodology}

The methodology consists largely of methods of primary survey, namely the questionnaire survey and individual interviews. The primary sources of data are the collected from panchayats elected members in the mysore district. The mysore district has 235 Grama Panchayats (GPs) in which 23 (10 per cent) respondent to a questionnaire. The total number of GPs elected members is 4300 , of which 215 ( 05 per cent) of respondent to a questionnaire. Samples were selected from all the taluks of the district.

Table 1 reveals that the age distribution of Panchayats presidents in mysore district, about 30.23 per cent members are in the age grup of $25-35 ; 45.58$ per cent in the age group of $36-45 ; 15.35$ per cent in the age group of 46-55 and 8.84 per cent members are above 56 years. If members belonging to the first two groups of 25-35 and 36-45 are added, the number of members under 45 years would come to 24.19 per cent. The age group distribution of the members proved that at the rural level younger generation were recruited to the rural political leadership in mysore district.

Table-1: Age Distribution of Panchayats presidents in Mysore District

\begin{tabular}{|l|r|r|}
\hline Age Groups & Total Numbers & \multicolumn{2}{|c|}{ Percentage } \\
\hline $25-35$ & 65 & 30.23 \\
\hline $36-45$ & 98 & 45.58 \\
\hline $46-55$ & 33 & 15.35 \\
\hline $56 \&$ above & 19 & 8.84 \\
\hline Total & $\mathbf{2 1 5}$ & $\mathbf{1 0 0 . 0 0}$ \\
\hline
\end{tabular}

Source: Primary survey 2013

Caste

Table 2 state that the caste wise distribution of panchayat presidents in mysore district. As far as the caste composition of the general population in the state is as concerned, percentage of SC in the district is 19.07; ST in the district is 8.37 per cent, BC-A is 9.77 per cent, BC-B is 2.79 per cent and General members is 60.00 per cent. It can be seen from table-2 that generally the caste composition of the Panchayat leadership is almost proportionate to the population except in the case of SC/ST. General over-dominate than other communities.

Table-2: Caste-wise Distribution of Panchayat presidents in Mysore District

\begin{tabular}{|l|r|r|}
\hline Age Groups & Total Numbers & \multicolumn{2}{|l|}{ Percentage } \\
\hline SC & 41 & 19.07 \\
\hline ST & 18 & 8.37 \\
\hline BC-A & 21 & 9.77 \\
\hline BC-B & 6 & 2.79 \\
\hline General & 129 & 60.00 \\
\hline Total & $\mathbf{2 1 5}$ & $\mathbf{1 0 0 . 0 0}$ \\
\hline
\end{tabular}

Source: Primary survey 2013

Education:

Table-3: Mysore District Panchayat Presidents Education and Age

\begin{tabular}{|c|c|c|c|c|c|c|c|c|c|c|}
\hline \multirow{3}{*}{ Education } & \multicolumn{10}{|c|}{ Age Groups } \\
\hline & \multicolumn{2}{|c|}{$25-35$} & \multicolumn{2}{|c|}{$36-45$} & \multicolumn{2}{|c|}{$46-55$} & \multicolumn{2}{|c|}{$56 \&$ Above } & \multicolumn{2}{|c|}{ Total } \\
\hline & Number & $\%$ & Number & $\%$ & Number & $\%$ & Number & $\%$ & Number & $\%$ \\
\hline No Education & 00 & 00 & 6 & 13.04 & 18 & 39.13 & 22 & 47.82 & 46 & 21.39 \\
\hline SSLC & 48 & 54.54 & 28 & 31.82 & 8 & 9.09 & 4 & 4.54 & 88 & 40.93 \\
\hline PUC & 29 & 74.35 & 8 & 20.51 & 2 & 5.13 & 00 & 00 & 39 & 18.14 \\
\hline Graduate & 12 & 60.00 & 5 & 25.00 & 3 & 15.00 & 00 & 00 & 20 & 9.30 \\
\hline Law Graduate & 2 & 100.00 & 00 & 00 & 00 & 00 & 00 & 00 & 2 & 0.93 \\
\hline PG & 4 & 36.36 & 6 & 54.54 & 1 & 9.09 & 00 & 00 & 11 & 5.12 \\
\hline Others & 5 & 55.55 & 3 & 33.33 & 1 & 11.11 & 00 & 00 & 9 & 4.19 \\
\hline Total & 100 & 46.51 & 56 & 26.05 & 33 & 15.35 & 26 & 12.09 & 215 & $\begin{array}{r}100.0 \\
0 \\
\end{array}$ \\
\hline
\end{tabular}

Source: Primary survey 2013

Table-3 reveals that the education of the panchayat members in the district. It is clearly shows that 21.39 per cent of the panchayat presidents are no education, 79.61 per cent of the presidents are literate. The 
matriculates account for the largest representation 40.93 per cent. The table further reveals that younger generation of the rural leadership is highly educated than the elder ones.

\section{Economic Background}

Table 4, reveals that the economic background of the panchayat presidents in mysore district, we have taken into account the rough annual income of the members of family having landed property,, value of the movable and immovable properties of the family, modern amenities / home appliances and occupation of the members. The table also indicate that majority of the members (58.14 per cent) are in the annual income group of below Rs. 15,000 per year. As per the response of the Panchayat presidents . 7.21 per cent of the members are eligible to pay income tax to the government.

Table-4: Annual Income of the Panchayat presidents in Mysore District (In Rupees)

\begin{tabular}{|l|r|r|}
\hline Age Groups & Total Numbers & Percentage \\
\hline Below 15,000 & 125 & 58.14 \\
\hline $15001-20000$ & 48 & 22.32 \\
\hline $20001-30000$ & 23 & 10.70 \\
\hline $30001-50000$ & 12 & 5.58 \\
\hline Above 50000 & 7 & 3.26 \\
\hline Total & $\mathbf{2 1 5}$ & $\mathbf{1 0 0 . 0 0}$ \\
\hline
\end{tabular}

Source: Primary survey 2013

Table 5 indicates the land holding pattern of the panchayat presidents in mysore district. Regarding below one acre land members, the data demonstrates that 45.16 per cent of the members are in this category, while 28.83 per cent hold to two acre of land. Land ownership pattern shows that only 1.86 per cent of them possess above five acres of land. It denotes the fact the landlords are not over repsresented in the rural political leadership.

Table-5: Land Holding of the Panchayat presidents in Mysore District

\begin{tabular}{|l|r|r|}
\hline Land holding & Total Numbers & \multicolumn{1}{|c|}{ Percentage } \\
\hline Below 1 acre & 97 & 45.16 \\
\hline 1 to 2 acre & 62 & 28.83 \\
\hline 2 to 3 acre & 25 & 11.62 \\
\hline 3 to 4 acre & 8 & 3.72 \\
\hline Above 5 acre & 4 & 1.86 \\
\hline Not Ascertained & 19 & 8.81 \\
\hline Total & $\mathbf{2 1 5}$ & $\mathbf{1 0 0 . 0 0}$ \\
\hline
\end{tabular}

Source: Primary survey 2013.

\section{Occupational Background}

Table 6 shows that the occupational background of the panchayat presidents in the district. Regarding their occupational background 27.44 per cent stated that they were cultivators, 31.62 per cent of respondents stated that they were fulltime political workers, 20.93 per cent are Agricultural labour, 10.69 per cent are engage in other occupation in the district. It shows that the option falls on agriculturists with regard to the rural political leadership of Mysore District

Table-6: Occupational Background of the Panchayat presidents in Mysore District

\begin{tabular}{|l|r|r|}
\hline Land holding & Total Numbers & \multicolumn{1}{l|}{ Percentage } \\
\hline Agriculture labours & 45 & 20.93 \\
\hline cultivators & 59 & 27.44 \\
\hline Political worker & 68 & 31.62 \\
\hline Merchant & 8 & 3.73 \\
\hline Trade union work & 2 & 0.93 \\
\hline Advocates & 10 & 4.66 \\
\hline Any others & 23 & 10.69 \\
\hline Total & $\mathbf{2 1 5}$ & $\mathbf{1 0 0 . 0 0}$ \\
\hline
\end{tabular}

Source: Primary survey 2013.

\section{Political status}

Political background of the members, 41.39 per cent of the panchayat presidents entered in politics between the age group of 18 and 25 years, 19.53 per cent of respondents are between age group of 26 and 35 years, 27.44 per cent are age group of 36 and 45 and 6.06 per cent of panchayat presidents are between age group of above 46 years. 
Socio-economic and political status of panchayats Elected representatives (A Study of ....

Table-7: Age-wise distribution of Panchayat President's getting membership in the party

\begin{tabular}{|l|r|r|}
\hline Age & Total Numbers & Percentage \\
\hline $18-25$ & 89 & 41.39 \\
\hline $26-35$ & 42 & 19.53 \\
\hline $36-45$ & 59 & 27.44 \\
\hline $46+$ & 13 & 6.06 \\
\hline Not ascertained & 12 & 5.58 \\
\hline Total & $\mathbf{2 1 5}$ & $\mathbf{1 0 0 . 0 0}$ \\
\hline
\end{tabular}

Source: Primary survey 2013.

Table-8: Panchayat Presidents level of education and contesting in the election while they were students in school/collge

\begin{tabular}{|c|c|c|c|c|c|c|c|c|}
\hline \multirow{2}{*}{ Level of education } & \multicolumn{2}{|c|}{$\begin{array}{c}\text { Contested in the } \\
\text { election }\end{array}$} & \multicolumn{2}{|c|}{$\begin{array}{c}\text { Not contested in the } \\
\text { election }\end{array}$} & \multicolumn{2}{|c|}{ Others } & \multicolumn{2}{|c|}{ Total } \\
\hline & Number & $\%$ age & Number & $\%$ age & Number & $\%$ age & Number & $\%$ age \\
\hline Under- Matriculate & 28 & 34.57 & 37 & 45.68 & 16 & 19.75 & 81 & 100 \\
\hline Matriculate & 12 & 18.46 & 32 & 49.23 & 21 & 32.31 & 65 & 100 \\
\hline PUC & 5 & 35.71 & 6 & 42.86 & 3 & 21.43 & 14 & 100 \\
\hline Graduate & 15 & 40.54 & 18 & 48.65 & 4 & 10.81 & 37 & 100 \\
\hline PG & 1 & 33.33 & 2 & 66.67 & 0 & 00.00 & 3 & 100 \\
\hline Law Graduate & 8 & 66.67 & 3 & 25.00 & 1 & 8.33 & 12 & 100 \\
\hline Not ascertained & 2 & 66.67 & - & 00.00 & 1 & 33.33 & 3 & 100 \\
\hline Total & 71 & 33.02 & 98 & 45.58 & 46 & 21.40 & 215 & 100 \\
\hline
\end{tabular}

Source: Primary survey 2013.

Table 8 also illustrate that there is some relationship between the level of education of panchayat presidents in politics. Higher the education of panchayat presidents, higher is their chance of participation in elections. If 34.57 per cent of under-matriculates contested in the school/college election, 35.71 per cent of the Pre-University, 40.57 per cent of the graduates, 66.67 per cent of the law graduates and 33.33 per cent of the post-graduates had contested in the school/college elections.

\section{Conclusions}

From the observations, analysis, study, inferences and conclusions, The rural population in mysore district opt for highly educated youngsters as presidents of their panchayats. Below one acre land members, the data demonstrates that 45.16 per cent of the members are in this category. The educational level shows that 21.39 per cent of the panchayat presidents are no education, 79.61 per cent of the presidents are literate. On a deeper and closer caste-wise examination of representation, it is noted that general are over represented, while SC/ST are under - represented. Inspite of the under representation of the SC/ST it is interesting to see a 27.44 representation of SC/ST among panchayat presidents. The upper middle class people have an edge over the rest. Majority of them are full time politicians. Majority of presidents are contesting for election their low income groups. The resent election majority of the presidents having highly educated. Occupational background of the panchayat members majority of the 27.44 per cent stated that they were cultivators, 31.62 per cent of respondents stated that they were fulltime political workers, 20.93 per cent are Agricultural labour, 10.69 per cent are engage in other occupation in the district.

\section{References:}

[1]. Vijayakumar (1996), Management of Panchayati Raj Institutions - A New Thrust Needed”, Southern Economist, July 15.

[2]. B.S. Bhargava (1982), "Panchayat Raj System in Tamilnadu", Panchayat Sandes, Jan.

[3]. Haricandran (1983), "Panchayat Raj and Rural Development", Concept, New Delhi.

[4]. Satya Sundaraqm (1991), "Better Deal for Rural Artisans", Financial Express, March 19. 